\title{
Notes on the Occurrence of Pea-Crab (Arcotheres Sp.) in Tegillarca granosa from Sundarban Mangroves, India
}

Dev Roy MK* and Nandi NC

Social Environmental and Biological Association, India

Submission: October 04, 2017; Published: December 22, 2017

*Corresponding author: : Dev Roy MK, Social Environmental and Biological Association, Kolkata, India, Email: malay_7@rediffmail.com

\section{Introduction}

During the course of survey work under the project on Macrozoobenthos of Hugli-Matla Estuary in March, 1989, the present authors collected and examined a number of Anadora granosa (currently known as Tegillarca granosa) from different mangrove sites of Sundarban. Out of 5 clam host specimens examined at Kishori mohan pur, pinnotherid crabs were detected in four clams $(80 \%)$ whereas all the 15 specimens of Prentice
Island, 2 specimens of Kalas and 1 specimen of Curzon creek were found to be infested by this crab. Lalitha Devi [1] reported Pinnotheres alcocki (now known as Arcotheres alcocki) from Anadara granosa (=Tegillarca granosa) at Kakinada bay. Later, the frequency and distribution of pea crabs in the clam A. granosa $(=$ Tegillarca granosa $)$ was investigated by Narasimham [2] while Pati et al. [3] recently recorded this crabin Meretrixcasta at Bahuda and Rushikulya estuaries in Odisha.

Table 1: Occurrence of Pea crab Arcotheres sp. in Tegillarca granosa at three sites (islands) of Sundarbans.

\begin{tabular}{|c|c|c|c|c|c|}
\hline \multicolumn{2}{|c|}{ Size of Tegillarcagranosa } & \multicolumn{2}{|c|}{ Size of Pea Crab } & \multirow{2}{*}{ Location in Valve } & \multirow{2}{*}{ Remarks } \\
\hline Length (mm) & Width (mm) & Length (mm) & Width (mm) & & \\
\hline \multicolumn{6}{|c|}{ Prentice Island (Date of Collection 08. 03. 1989) } \\
\hline 32 & 21 & 13 & 10 & $\mathrm{R}$ & Ovigerous \\
\hline 62 & 39 & 8.5 & 7 & $\mathrm{R}$ & Non-ovigerous \\
\hline 51 & 33 & 11.5 & 10 & $\mathrm{R}$ & Ovigerous \\
\hline 45 & 29 & 13.5 & 11 & $\mathrm{R}$ & Ovigerous \\
\hline 57 & 38 & 11.5 & 9.5 & $\mathrm{~L}$ & Ovigerous \\
\hline 47 & 32 & 8 & 6.5 & $\mathrm{R}$ & Non-ovigerous \\
\hline 60 & 38 & 11.5 & 10 & $\mathrm{R}$ & Ovigerous \\
\hline 45.5 & 30 & 13 & 19.5 & $\mathrm{R}$ & Ovigerous \\
\hline 52 & 34 & 12 & 10.5 & $\mathrm{R}$ & Ovigerous \\
\hline 61 & 38.5 & 12 & 11 & $\mathrm{R}$ & Ovigerous \\
\hline 40 & 31 & 12.5 & 11 & $\mathrm{R}$ & Ovigerous \\
\hline 74 & 44 & 14 & 12 & $\mathrm{R}$ & $\begin{array}{l}\text { Ovigerou; also two } \\
\text { juveniles on left valve }\end{array}$ \\
\hline 54 & 37 & 11.5 & 10 & $\mathrm{~L}$ & Ovigerous \\
\hline 47 & 31 & - & - & $\mathrm{R}$ & Juvenile \\
\hline 37 & 25 & 12 & 9.5 & $\mathrm{~L}$ & Ovigerous \\
\hline \multicolumn{6}{|c|}{ Kalas (Date of Collection 10. 03. 1989) } \\
\hline 29 & 19 & 8.5 & 7.5 & $\mathrm{~L}$ & Ovigerous \\
\hline 29 & 19.5 & 10 & 8.5 & $\mathrm{R}$ & Ovigerous \\
\hline \multicolumn{6}{|c|}{ Charland Near Curzon Creek (Date of Collection 09. 03. 1989) } \\
\hline 41 & 28 & 11.5 & 9 & $\mathrm{R}$ & Ovigerous \\
\hline
\end{tabular}


Oceanography \& Fisheries Open access Journal

\begin{tabular}{|c|c|c|c|c|c|}
\hline \multicolumn{7}{|c|}{ Kishorimohanpur (Date of Collection 07. 03. 1989) } \\
\hline 56 & 37 & - & - & $\mathrm{R}$ & $\mathrm{R}$ \\
\hline 47 & 30 & - & - & $\mathrm{R}$ & Ovigerous \\
\hline 56 & 35 & - & - & $\mathrm{R}$ & Ovigerous \\
\hline 55 & 34 & - & - & - & Ovigerous \\
\hline 40.5 & 25 & - & - & Without crab \\
\hline
\end{tabular}

From the perusal of literature, it appears that this is the first report of the occurrence of Arcotheres sp. in Tegillarca granosa from West Bengal coast. An analysis of the frequency of occurrence of pea-crabs in Tegillarca granosa presented in Table 1 reveals their presence mostly in the right valve. In the present study, one crab was noticed within the mantle cavity in 21 of 23 clam hosts examined. A single clam of Prentice Island was, however, found to harbour a single ovigerous female in the right valve and two juveniles in the left valve, while only one was free from pea crab infestation. This corroborates the observation of Narasimham [2] who reported multiple occupations as uncommon $(2.0 \%)$ for P. Alcocki occupying the mantle cavity of A. granosa (= Tegillarca granosa) in Kakinada Bay. During this investigation, no damage to soft parts of the host was noticed.
Similar observation was also reported by Narasimham [2] from Kakinada bay. It is also evident from the present investigation that size of clam has no bearing upon the number/and or size of pea crab.

\section{References}

1. Lalitha Devi S (1981) Some aspects of biology and effect of infestation on Pinnotheres placunae Hornell and South well of Kakinada Bay. J mar biol Ass India 28(1-2): 113-123.

2. Narasimham KA (1988) Biology of the blood clam Anadara granosa (Linnaeus) in Kakinada bay. J mar biol Ass India 30(1-2): 137-150.

3. Pati P, Sahu BK, Panigrahy RC (2015) Pea crab Arcotheres alcocki (Rathbun, 1909) asendoparasite of the backwater clam Meretrixcasta (Chemnitz, 1782). Indian J Geo-Marine Science 44(7): 1067-1070.

\section{Your next submission with Juniper Publishers will reach you the below assets}

- Quality Editorial service

- Swift Peer Review

- Reprints availability

- E-prints Service

- Manuscript Podcast for convenient understanding

- Global attainment for your research

- Manuscript accessibility in different formats ( Pdf, E-pub, Full Text, Audio)

- Unceasing customer service

Track the below URL for one-step submission https://juniperpublishers.com/online-submission.php 